Wright State University

CORE Scholar

$7-2016$

\title{
Civil Society and the Governance of Urban Food Systems in Sub- Saharan Africa
}

Daniel N. Warshawsky

Wright State University - Main Campus, daniel.warshawsky@wright.edu

Follow this and additional works at: https://corescholar.libraries.wright.edu/uag

Part of the Geography Commons, and the Urban Studies and Planning Commons

\section{Repository Citation}

Warshawsky, D. N. (2016). Civil Society and the Governance of Urban Food Systems in Sub-Saharan Africa. Geography Compass, 10 (7), 293-306.

https://corescholar.libraries.wright.edu/uag/20

This Article is brought to you for free and open access by the Geography at CORE Scholar. It has been accepted for inclusion in Geography Faculty Publications by an authorized administrator of CORE Scholar. For more information, please contact library-corescholar@wright.edu. 


\title{
Civil Society and the Governance of Urban Food Systems in Sub-Saharan Africa
}

\author{
Daniel N. Warshawsky* \\ Department of Urban Affairs and Geography, Wright State University
}

\begin{abstract}
Rapid urbanization of the planet has placed pressure on humanity to build sustainable, healthy, and socially just cities. In particular, key challenges associated with food access threaten the livability of the urban environment. For this reason, research on urban food systems has increased significantly, as scholars have studied the production, distribution, acquisition, consumption, and waste of food. However, key research gaps persist, as it remains unclear how urban food systems are governed and the roles that different institutions play to ensure that cities are livable. In particular, while food civil society organizations (FCSOs) have emerged as important players in urban food systems in lower-income regions such as Sub-Saharan Africa, FCSOs are poorly understood. This has resulted in an inadequate theorization of their institutional roles, governance structures, and potential impacts. To fill this critical research gap, this paper analyzes the roles of FCSOs, including the range of food non-governmental organizations (FNGOs), food community-based organizations (FCBOs), and food social movements (FSMs) in Sub-Saharan Africa. While this paper highlights the range of scholarship devoted to urban food systems, key empirical and theoretical gaps remain unanswered by scholars. Importantly, the size, structure, and spatiality of urban food systems are not well understood. In addition, it remains unclear how FCSOs intersect with broader political, economic, and social processes of inequality. Moreover, given the range of informal livelihood strategies that urban residents utilize to access food, more scholarship is needed to understand the innovative ways that FSCOs are integrated into the daily lives of people residing in Sub-Saharan Africa.
\end{abstract}

\section{Introduction}

Urban food insecurity ${ }^{1}$ has emerged as one of the most pressing and misunderstood problems in the world, especially in regions such as Sub-Saharan Africa where the pace of urbanization in low-income countries has contributed to the rise of poverty in cities (Clapp and Cohen 2009; Cohen and Garrett 2010; Morgan 2009). The percentage of urban residents in Sub-Saharan Africa has increased from $13 \%$ in 1950 to $37 \%$ in 2014. By 2050, urban growth rates in SubSaharan Africa are expected to be the fastest in the world, as the continent's urban population triples and the urban proportion increases from 37\% to 55\% (United Nations 2014). With these numerical indicators pointing to the growth of urban food insecurity, it is likely that urban food governance will become increasingly difficult over the next half-century (Wiskerke 2015).

In addition, urban food access also differs from rural food access in important ways. For this reason, urban food systems require unique analytical attention by scholars. Although the rural-urban food system divide is fluid, ${ }^{2}$ urban food insecurity exists as a result of structural inequality associated with the political economy of food inaccessibility, poverty and income inequality, and uneven global food flows, not the availability of food (Clapp and Fuchs 2009; Crush and Frayne 2011; Maxwell 1999; Riches and Silvasti 2014). For this reason, households' income levels and purchasing power in the cash economy are critical, especially in informal 
street vendors and secondary markets. In addition, households engage in a range of informal livelihood strategies to secure food, such as growing food, sharing food, and reusing 'wasted' food (Crush and Frayne 2010; Simone 2014). To this end, many scholars have examined the range of private, public, and non-governmental organizations which operate across scales and sectors in urban food systems in Sub-Saharan Africa (Atkinson 1995; Battersby 2012, 2013; Crush and Frayne 2010; Drakakis-Smith 1990, 1991; Frayne 2010; Morgan 2009; Moseley 2001; Rocha and Lessa 2009).

As part of the 'third sector' or broader social economy (Pearce 2009; Tostensen et al. 2001), food civil society organizations ${ }^{3}$ (FCSOs) have emerged as one of the most important institutions to confront urban food insecurity in Sub-Saharan Africa. FSCOs provide critical social services in places where the state or private sector fails to meet basic needs (Warshawsky 2014a), increase awareness of critical food challenges facing cities, and contribute to the growth of urban social movements (Bond 2006; Greenberg 2006). Yet, even though FSCOs have grown in importance, they remain poorly understood by scholars (Warshawsky 2013, 2014b). This has resulted in an inadequate conceptualization of FCSOs' institutional roles, governance ${ }^{4}$ structures, $^{2}$ and potential impacts. To fill this critical research gap, this paper analyzes the governance of urban food systems in Sub-Saharan Africa, with particular attention to the roles of FCSOs.

The structure of the paper is as follows. After conceptualizing the governance of urban food systems and changing state-civil society relations in Sub-Saharan Africa, this paper examines the roles of FCSOs and areas for future research in the field of geography. While this paper highlights the range of scholarship devoted to urban food systems, key empirical and theoretical gaps exist to fully understand how FCSOs operate in urban food systems. In particular, the size, scope, and spatiality of urban food systems continue to be poorly theorized, and it remains

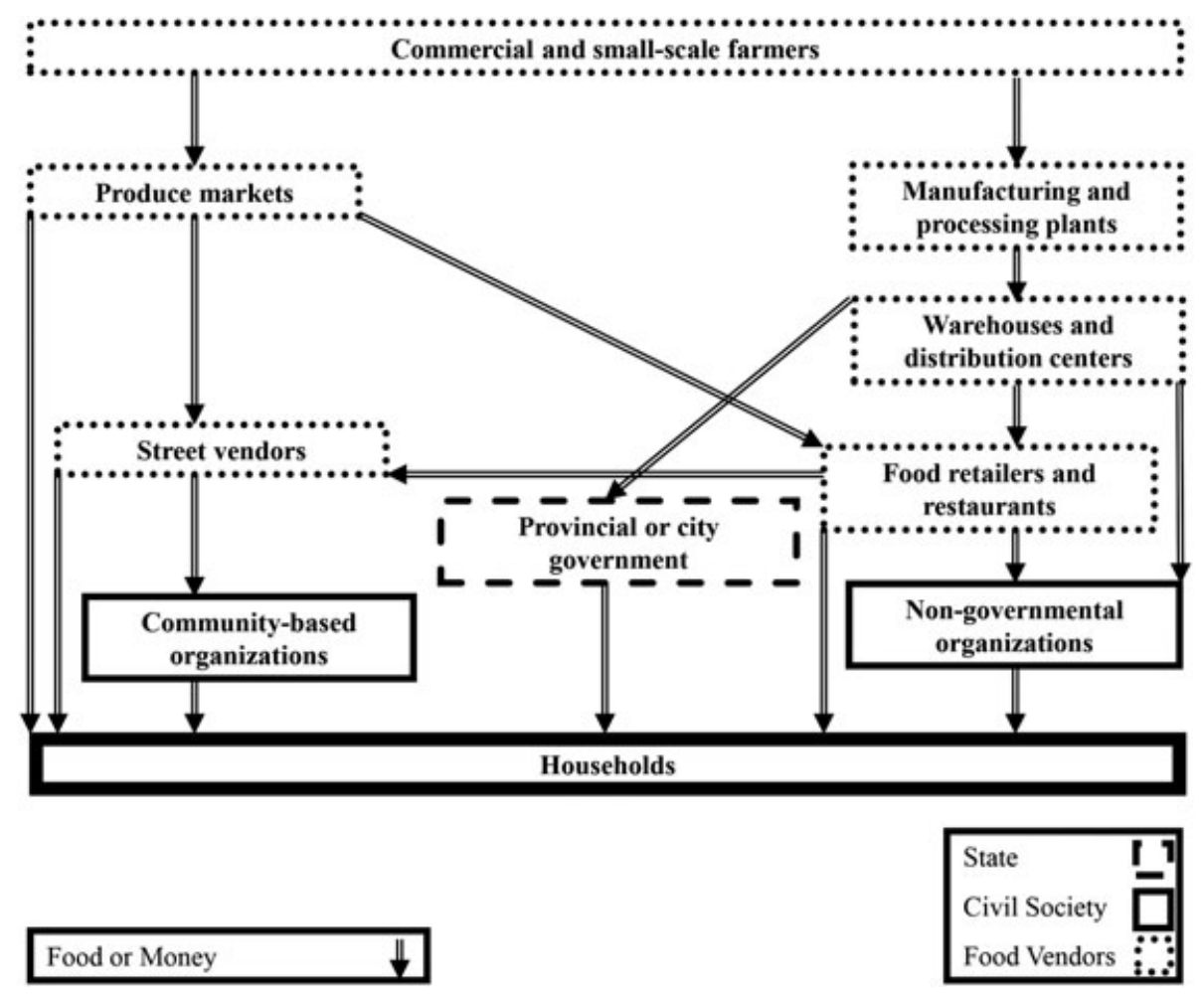

Fig. 1. The urban food system in Sub-Saharan Africa. 
unclear how FCSOs and informal livelihood strategies intersect with broader political, economic, and social processes of inequality. These gaps suggest that scholars need to critically analyze the urban governance of food and other basic human needs in order to accurately conceptualize urban food systems, promote more effective policy, and improve livelihoods for the urban poor.

\section{State, Civil Society, and the Governance of Urban Food Systems in Sub-Saharan Africa}

According to key studies (Atkinson 1995; Drakakis-Smith 1990, 1991; Frayne 2010; Moseley 2001), a range of private, public, and non-governmental institutions are active in urban food systems (Figure 1). According to a recent paper on urban food access in Southern Africa (Crush and Frayne 2010), city dwellers access food primarily through supermarkets (79\%); informal markets and street food (70\%); and, small shops, restaurants, and take away (68\%). In addition to the range of informal street vendors and formal food retailers which are scattered across urban food systems, governments deliver social welfare programs (Devereux 2001; Satterthwaite and Mitlin 2014) and regulate the food economy through the implementation of tariffs and exchange rates for imported food, use of food price subsidies and price ceilings, and development of regional trade policies (Maxwell 2001; Stevens and Kennan 2001). FCSOs promote urban agriculture, emergency food services, and mobilize food social movements (FSMs) (Atkinson 1995; Warshawsky 2013, 2014); and food corporations promote their philanthropic initiatives (Roy 2010).

In addition to these more formalized institutions, households engage in a range of social processes to secure food (Battersby 2013; Crush and Frayne 2010; Crush et al. 2011; Webb 2011). This includes borrowing, gifting, or bartering food for religious or cultural reasons; dumpster diving or scavenging for food; receiving food through charity, food aid, or begging; remittances from rural-urban migration; collecting food from urban livestock or urban forests; accepting food for sex or entertainment; or, stealing food. Although it is difficult to precisely measure how many people utilize these practices, scholars have suggested that informal livelihood strategies are important in the daily life for many, if not most people in urban Sub-Saharan Africa (Crush and Frayne 2010; Simone 2004).

As conceptualizations of food systems have transformed over the last few decades, a range of institutional players have been identified as key to reducing urban food insecurity (Maxwell 2001). In the 1970s, global and national food supply crises were linked to food insecurity. For this reason, states focused on maximizing the amount of internal food production and accepting food aid when necessary to ensure adequate food supplies. Yet, as noted by Sen (1981) and Drakakis-Smith (1990), positive balances of food production at the national level do not necessarily ensure food security, as local food access is complicated by cultural and social processes operating at the household and community scales (Koc et al. 1999).

However, these important shifts in thinking were sidelined as extreme economic crises in many Sub-Saharan countries refocused food policy towards macroeconomic stability and financial discipline through the implementation of structural adjustment programs (SAPs). In the 1980s and 1990s, SAPs profoundly changed food policy in Sub-Saharan Africa as the World Bank and International Monetary Fund provided loans to many countries ${ }^{5}$ on the condition that they emphasize fiscal balance over state-led poverty reduction or other programs designed to meet basic needs (Dixon et al. 1995; Riddell 1992; Sahn et al. 1999). Also, SAPs had a significant impact on middle and low-income urban residents in small, medium, and large cities across Sub-Saharan Africa, as food price fluctuations, wage freezes, and reduced central state ${ }^{6}$ spending limited the capacity of city dwellers to afford high quality food in consistent measure (Tostensen et al. 2001). 
Since 2000, food policy in Sub-Saharan Africa has been strongly influenced by the UN's Millennium Development Goals (MDG) which have aimed to reduce extreme poverty and achieve increased global health across the planet (United Nations 2016a). MDGs are designed to be quantifiable and achievable in clearly delineated timeframes. Although the UN touts the success of the MDGs (United Nations 2016a), some scholars have argued that the MDGs have not only been unrealized but actually reinforce uneven development, extreme hunger, and poverty (Fukuda-Parr et al. 2014; Satterthwaite 2016). As noted by Hickel (2016) and McMichael and Schneider (2011), the MDGs and their subsequent repackaging into the Sustainable Development Goals (SDG) (United Nations 2016b) may use problematic definitions of poverty which mispresent the extent of poverty and reinforce a false narrative that large scale export oriented agricultural development is the only way to reduce extreme poverty. According to these scholars, MDGs and SDGs ignore the structural causes of poverty and inequality and fail to address why people are poor in the first place.

Even with the influence of these global policies, the central state remains key in urban food systems in many parts of Sub-Saharan Africa (Devereux 2001; Maxwell 2001; Satterthwaite and Mitlin 2014). The central state has been important in producing food policy, trade laws and tariffs, food prices, market regulations, and government food assistance programs (Stevens and Kennan 2001). In particular, the central state is often tasked with determining the amount and types of foods are for export versus internal consumption. At the more local level, provincial and city level governments develop local markets, regulate the informal economy, and promote food assistance programs (Atkinson 1995; Baker and de Zeeuw 2015).

As the Washington Consensus and SAPs have become increasingly critiqued, 'third way' public-private partnerships and other governance models emerged in the 1990s and 2000s as a way to promote multi-sector collaborations among public, private, and civil society organizations, reduce state expenditures, and incorporate local actors (Atkinson 1995; Duncan 1998; Habib and Kotzé 2003; Tostensen et al. 2001). As part of this process, the central state has reduced its size and devolved responsibility to local non-state actors. This has resulted in increased pressure on FCSOs to ensure food security for urban residents.

On the one hand, some have suggested that this governance shift has created an opening for FCSOs to work with the state or create new democratic spaces of community participation. In this perspective, 'pro-growth' and 'pro-poor' policies are not necessarily incompatible (Eastwood and Lipton 2002; Parnell and Robinson 2006; Satterthwaite and Mitlin 2014). For many others, these governance shifts are interpreted as evidence of an entrenched neoliberalism that promotes the role of FCSOs while also increasing inequality and poverty in the name of economic development (Bond 2000; Silva 2009).

However, this latter reading of the state is problematic, as countries in Sub-Saharan Africa have implemented neoliberal policies in uneven ways for historically contingent and placespecific reasons (Ferguson 2007; Leitner et al. 2007). Also, as noted by Bunnell (2015), Cox and Negi (2010), Glassman and Samatar (1997), Mercer et al. (2003), and Silvey and Rankin (2010), a range of critical political economy, postcolonial, and other integrative approaches are needed to understand the extent of state experiences in Sub-Saharan Africa. Moreover, as noted by scholars working in Sub-Saharan Africa (Beall et al. 2002; Parnell and Robinson 2012; Pieterse and Parnell 2014; Pieterse et al. 2008), urban governance is often determined by variables which may not be the result of neoliberalism only. This includes extreme social inequality; government corruption; extreme poverty and the growth of informal settlements; violence based on race, gender, and place of origin; and persistence of debilitating health crises. To this end, scholars need to recognize the multiplicity, dynamism, and hybridity of urban governance regimes in Sub-Saharan Africa (Comaroff and Comaroff 2012; Edensor and Jayne 2012). 


\section{Food Civil Society Organizations in Sub-Saharan Africa}

Conceptualizing Civil Society

In Sub-Saharan Africa, there are many ways to conceptualize FCSOs. Because of the partiality of legal and functional definitions of FCSOs, Salamon and Anheier (1992) developed a relatively influential system to analyze the range of CSOs across the planet, including FCSOs. According to this 'structural-operational' definition, CSOs are defined as formal, non-profit, and voluntary. Although this relatively detailed definition has grown in influence across the globe (Salamon et al. 2003), many scholars have critiqued this conceptualization as a problematic theorization, especially in the Sub-Saharan African context.

To start, critical development scholars have argued that CSOs need to be conceptualized as dynamic, hybrid, relational, and socially constructed as the product of particular histories in local contexts (Comaroff and Comaroff 1999). Even with these critiques, civil society has remained an important concept to understand and theorize, even if imperfect (Tostensen et al. 2001). Yet, as noted by Bebbington et al. (2008), Edwards and Hulme (1996), and Ferguson (2006), CSOs have been limited by reduced accountability, lack of clear outcomes, and reproduction of the status quo. In addition, other scholars have been critical of the romanticization of local initiatives (Born and Purcell 2006; Mohan and Stokke 2000; Srinivas 2009), intra-NGO competition (Bond 2008; Roy 2010), and corporate influence in the NGO sector (Mohan 2002; Warshawsky 2014b).

In some Sub-Saharan contexts, scholars note that many conceptualizations of CSOs reinforce the false idea that wealthy communities are necessary to give resources to the poor. Yet, as noted by Habib et al. (2008), people within poor communities also engage in significant patterns of resource exchange. Also, while many conceptualizations of CSOs utilize the nuclear family as a starting point, analysis of CSOs in Sub-Saharan Africa illustrates that the extended family is arguably a more useful category when studying altruism, giving, and development of CSOs (Habib et al. 2008; Seleoane 2008). Moreover, the range of CSOs is quite diverse in type and this is related to religious and cultural variation in different communities across the globe (Maharaj et al. 2008).

To attend to these conceptual challenges in the Sub-Saharan African context, Habib (2005), Habib and Kotzé (2003), and Tostensen et al. (2001) developed a conceptual heuristic to differentiate CSOs by form, function, and mission. This includes non-governmental organizations (NGOs), community-based organizations (CBOs), and social movements (SMs). Building on this influential tri-partite conceptualization, I have suggested that this analytical heuristic is a useful typology to understand the landscape of FSCOs in Sub-Saharan Africa (Warshawsky 2013, 2014a). While the presence of these three types of FSCOs is unevenly distributed across Sub-Saharan Africa given that the political economy of countries and regions is tied to unique historical patterns of development and underdevelopment, this three-part heuristic is useful in delineating the broad types of FCSOs which exist across Sub-Saharan Africa. In this way, while no heuristic can encompass all types of FCSOs in all contexts, this three part conceptualization is an important means of understanding the various types of FCSOs which exist in Sub-Saharan Africa.

First, food non-governmental organizations (FNGOs) manage food production in cities and deliver food philanthropy in coordination with food businesses. In Sub-Saharan Africa, FNGOs are generally resourced by private sources and located in middle class communities either locally or abroad. In this way, FNGOs tend to be larger, highly professionalized, and often tied to elite networks. Very often FNGOs work with a network of more localized organizations that have more direct contact with the communities they serve (Bebbington 
et al. 2008; Edwards and Hulme 1996; Habib 2005; Habib and Kotzé 2003; Mohan 2002; Srinivas 2009).

Second, food community-based organizations (FCBOs) operate a range of food programs for vulnerable populations. This includes hot meals, non-perishable items, and other basic needs. FCBOs tend to be highly dependent on resources internal to the lower-income communities they serve. In this way, FCBOs are relatively disconnected from elite multi-scalar networks of money and resources that FNGOs access. Importantly, some FNGOs and FCBOs operate in place of non-existent or failing state food programs, while others work with national or international governing institutions. Additionally, while some FCSOs are global institutions in size and scope, many FNGOs and FCBOs are localized and firmed rooted in particular communities (Tostensen et al. 2001; Warshawsky 2013, 2014a).

Third, FSMs often operate on broader political, economic, or social issues ranging from land reform to food prices. Typically, FSMs focus more on challenging the central state or agribusinesses than providing food to the poor through service delivery (Ballard et al. 2006; Thompson and Tapscott 2010; Warshawsky 2014a).

The Limits of Current Research on Local Food Organizations

Most recently, scholars have analyzed how FCSOs intersect with the range of informal livelihood strategies in the Global South, such as urban agriculture (Crush et al. 2011; De Bon et al. 2010; Freidberg 2001; Webb 2011; Zezza and Tasciotti 2010) and urban-rural cross migration patterns (Crush and Frayne 2010; Frayne 2010). Additionally, geographers have also been central in identifying how FCSOs intersect with gendered processes of inequality (Hovorka 2005), racialized processes of exclusion (Warshawsky 2014b), and environmental challenges associated with climate change at local scales (Bohle et al. 1994; Parnell et al. 2007).

Yet, while geographers have been keen to analyze food initiatives in Sub-Saharan Africa, such as diversification of income-generating strategies and production of urban agriculture, the central state remains key in reproducing the context where local initiatives are likely to develop (Atkinson 1995; Duncan 1998; Maxwell 1999, 2001). This research disproportionately focuses on urban agriculture, even though it is used by less than $20 \%$ of residents in many parts of Sub-Saharan Africa (Battersby 2013; Crush et al. 2011). Although urban agriculture is surely a positive development in many contexts, it seems unlikely that it can be the 'magic bullet' to overcome the structural limitations present in many cities in Sub-Saharan Africa. In some cases, social movements have emerged to contest inequality produced by state policies or corporate interests; however, these FSMs tend to be insignificant in size or part of broader 'pro-poor' social movements (Ballard et al. 2006; Bond 2000; Heller and Evans 2010; Thompson and Tapscott 2010).

In addition, while scholars' focus on the community and household scale have provided important insights into the livelihoods strategies of the urban poor in Sub-Saharan Africa, it is uncertain how multi-scalar processes of resistance intersect with broader structural forces which shape political economic reality for the urban food insecure. For these reasons, more research attention ought to focus on the multi-scalar and multi-sectoral institutional relationships which reproduce food insecurity in cities of Sub-Saharan Africa. Moreover, many of the key studies on urban food insecurity (Atkinson 1995; Drakakis-Smith 1990, 1991; Moseley 2001) are not only aging each year but cannot account for the vast diversity of FCSOs which operate in other contexts across Sub-Saharan Africa. ${ }^{7}$

While FCSOs are often promoted as a way to produce more livable environments, it is unclear if FCSOs are capable of achieving these goals. Although scholars have analyzed urban food 
systems in increasing frequency (Feagan 2007; Gottlieb and Joshi 2010; Heynen et al. 2012; Sonnino 2014), FCSOs remain relatively understudied, especially in Sub-Saharan Africa. Centrally, the spatial distribution, organizational structure, institutional roles, and impacts are unknown. Most importantly, given that urban food insecurity is increasing primarily in regions such as Sub-Saharan Africa where institutional capacity is constrained by persistent poverty, rapid in-migration, and the debilitating effects of HIV/AIDS (Parnell and Robinson 2012; Rakodi 1997), it is critical to determine whether FCSOs can improve the lives of the urban poor in these rapidly transforming regions of the world.

\section{Key Research Gap: Civil Society and the Governance of Urban Food Systems}

Thus far, this paper has critically examined the roles of FCSOs in Sub-Saharan Africa. While the literature on the urban food systems has increased recently, scholars tend to focus on livelihoods strategies of the urban poor, such as the diversification of income-generating strategies (Simone 2014) and the production of urban agriculture (Zezza and Tasciotti 2010) without adequately attending to the multi-sectoral and multi-scalar processes that often produce the context in which FSCOs develop (Maxwell 1999). In addition, although scholars have identified key roles for key urban food institutions, including the state food policy (Devereux 2001; Maxwell 2001), informal street vendors (Tinker 1997), and formal corporate philanthropies (Louw et al. 2007), there are many research frontiers which remain understudied. For this reason, this paper has suggested that more research is needed to understand the roles of FCSOs in urban governance structures in Sub-Saharan Africa.

To start, scholars ought to identify the institutional roles, governance structures, and potential impacts of the state, private sector, and CSOs in urban food systems (Moragues-Faus and Morgan 2015). As part of this research, future scholarship should delineate the spatial structure of the food system and examine the key political-economic and social processes which reproduce urban food systems. Through this research, it should become clearer what roles institutions at different scales can and should play in food systems. In addition, while it is clear that a range of institutions are necessary for urban food systems to function effectively and equitably, more research is needed to understand how FCSOs contest and negotiate broader structural forces associated with global capital flows and state policy.

In addition, given the growth of informal settlements across many regions in the world, it is important to examine the ways in which FCSOs operate in conjunction with or against the state and food businesses, as FCSOs utilize a range of the informal livelihood strategies and place specific mechanisms to contest and negotiate broader social processes. While these relationships may be co-optive or predatory in nature, it is also likely that cooperative relations exist as well. In Sub-Saharan Africa, the landscape typically includes FNGOs and FCBOs working with capital as well as FCBOs and FSMs that operate outside the confines of partnerships with capital or the state. It is expected that these relationships are multiple and dynamic and operate differently at different scales. Thus, while FCSOs may operate with particular institutional strategies or structures in one city, governance structures vary by space and time. Given the range of CSO experiences in the African cities, it is disingenuous to characterize their existence as either the 'magic bullet' or evidence of an unjust neoliberalism, as FCSOs reflect a range of power relations depending on their form, function, and funding (Warshawsky 2014a).

Also, as noted by a range of post-colonial scholars examining global urbanization (McFarlane 2008, 2011; McFarlane and Robinson 2012; Robinson 2006, 2011; Roy 2005, 2011), the structure and experiences of urban life in Sub-Saharan Africa should not be defined as exceptional nor marginal to urban theory. Given that the world's cities reflect a range of urban experiences which do not mirror Western or Northern ideal city-types or spatial-historical contexts 
of previous time periods, it is clear that FCSOs in Sub-Saharan Africa deserve their own attention by scholars. In addition, although it is important to recognize the range of extreme political, economic, and social challenges in Sub-Saharan Africa, it is also critical not to reproduce a discourse of urban pathology or inevitability in which FCSOs react passively to structural processes of inequality (Davis 2006).

As noted by Simone (2007, Simone 2014), city dwellers across the world have actively reinvented their own lives through innovative social and economic practices at the local scale. In regards to food access, urban residents have developed creative methods to diversify the number and type of pathways to food access outside the cash economy. This includes sharing food within communal spaces, growing food, migrating between urban and rural spaces to access food or work, and developing new income streams through contingent or informal labor opportunities (Crush and Frayne 2010; Frayne 2010). Although many of these local initiatives may be highly unstructured, fleeting, unsuccessful, or exaggerate the power of FCSOs to produce change, Myers (2011) suggests that these urban experiences should not be defined as chaotic or unimportant. In contrast, as Simone (2014) states, many local initiatives are arguably highly logical and creative outgrowths of the complex urban environments where people live. In addition, as noted by Jacobs (2012), Peck and Theodore (2010), and Parnell and Robinson (2012), given that FCSOs are often developed in relation to structures which may not be localized, it is important for scholars to use a process-oriented approach which follows the development of FSCOs relationally to examine the context in which FSCOs evolve.

Geographers are arguably in a good scholarly position to fill these research frontiers on FCSOs. As scholars who are invested in both extensive methods which generalize based on the replicability and representativeness of a collectable set of data and intensive methods which aim to reveal the causal mechanisms central to social processes (Sayer 1992; Warshawsky 2014b), many geographers have the conceptual and methodological skill sets to produce theoretically and empirically rigorous studies on the role of FCSOs in urban food systems.

Clearly, a focus on the urban governance of food systems is not just about producing scholarship which is rigorous and well-argued, as geographers are also well-positioned to make a broader contribution to policy and the livelihoods of actual people in the world's cities. Geographers can not only clarify how important socio-spatial trends operate, but also help improve service delivery and the quality of life for those living in the rapidly urbanizing contexts in Sub-Saharan Africa and other regions throughout the Global South. As noted by the Food and Agriculture Organization (2009), it is critical to understand the institutions which determine the food security context if we are serious in our efforts to address food insecurity:

Understanding governance structures and institutional contexts is crucial for addressing food security as a policy issue that cuts across several sectors and has multiple dimensions. It is now recognized that the institutional set-up and the processes that allow interactions among stakeholders are critical factors for success or failure when formulating, implementing, and monitoring policies, strategies, and programmes (Food and Agriculture Organization 2009: 47).

Moreover, this research has particular relevance today as the 'silent tsunami' (Sullivan 2008) of sharp food price increases and rising food insecurity in 2008 and 2011 reveal the need to understand how institutions in different sectors and scales contribute to food security for the urban poor. As urban residents are disproportionately dependent on purchasing food to meet nutritional needs, the contemporary food insecurity crisis is a particularly urban crisis. This tends to be unnoticed until natural disasters or severe price fluctuations 'scale up' food insecurity issues from an individual or household problem to an urban or national crisis (Maxwell 1999). Of note, food price crises recently evolved into revolutions which swept across the Middle East 
in 2010-2011 Arab Spring (Cohen and Garrett 2010; Cohen and Smale 2011). For all of these reasons, it is important for scholars to critically examine how FCSOs and other key institutions ensure that urban food systems operate effectively and equitably.

\section{Conclusion}

Given the constant pressures from extreme political, economic, social, and historical processes associated with the legacies of colonialism; neoliberal development and globalization; government corruption and extreme service backlogs; inept economies and high unemployment; persistent poverty and the growth of informal settlements; extreme health crises; and violence by race, class, gender, and place of origin (Parnell and Robinson 2012), this paper has suggested that it is unclear how, if at all, FCSOs can achieve their institutional goals to reduce food insecurity and empower communities in Sub-Saharan Africa.

While there are a number of important research frontiers which scholars ought to examine regarding the governance of urban food systems (Moragues-Faus and Morgan 2015), a few areas are especially important for future research. First, given the increased number and type of urban pathways to food in cities, it is important that scholars examine the range of informal livelihood strategies that urban residents utilize to access food. Although many FCSOs are challenged by global processes of inequality (Clapp and Cohen 2009; Morgan 2009), regional social crises (Myers and Murray 2006; Parnell and Robinson 2012), and issues specific to particular contexts, such as governance failure (Ferguson 2006; Pieterse et al. 2008) or urban violence (DeVerteuil 2015; Eakin et al. 2010), increased scholarly attention is needed to understand the innovative ways FSCOs are integrated into the daily lives of people residing in the Global South.

To complete this work, scholars should utilize a range of methods to trace the development of FSCOs relationally in different contexts (Jacobs 2012). In particular, scholars should develop a baseline study which examines the range of food procurement strategies utilized by households. Ideally, this study would use a relatively large sample size in multiple cities across different contexts. As part of this research, it would be important to examine how, if at all, FCSOs are part of those food procurement strategies and the methods by which key governing institutions, such as the state and agribusinesses, regulate and influence such activities.

In all, this paper has suggested that more attention is needed to understand the multi-scalar and multi-sectoral dynamics of urban food systems in Sub-Saharan Africa and other regions across the Global South. In particular, by identifying the structure and institutional relations operating in urban food systems in rapidly urbanizing areas, geographers can clarify the roles that institutions can and should play in reducing urban food insecurity. To this end, the research agenda proposed in this paper is not only an academic concern, but also central to effective policy and improved livelihoods of the urban poor. Moreover, given that many geographers are trained with multiple methods and epistemologies, geographers are well-positioned to examine the intrinsically interdisciplinary aspects of urban food systems.

\section{Notes}

* Correspondence address: Daniel N. Warshawsky, Department of Urban Affairs and Geography, Wright State University, 311 Millett Hall, 3640 Colonel Glenn Highway, Dayton, OH 45435, USA. E-mail: daniel.warshawsky@wright.edu

\footnotetext{
1 Food security is defined as the state of being when food is physically available; economically and physically accessible; safe, nutritious, and able to be consumed; and stable over time in various cultural and socio-demographic contexts at different scales (Food and Agriculture Organization 2008; Koc et al. 2008).

${ }^{2}$ Rural residents sometimes migrate to cities to find work, sell products, or access services, while city dwellers occasionally travel to rural areas to access food markets or reconnect with previous social networks (Garrett and Ruel 1999).
} 
${ }^{3}$ I use Tostensen et al. (2001) to define civil society as a fluid and dynamic category that includes all social activity which is not part of the state, private sector, or households.

${ }^{4}$ Urban governance is defined as the shift towards multi-sector collaborations among public, private, and nongovernmental institutions rather than state policy. This includes a shift in state-civil society relations, new conceptions of territoriality, recast citizenship, and increased governmentality (Brenner and Theodore 2002; Pieterse et al. 2008).

5 SAPs were enacted in Sub-Saharan African countries as a way to stabilize national economies and promote economic growth. The range of experiences associated with SAPs in Sub-Saharan Africa is varied and has been explored by many scholars (Sahn et al. 1999; van der Hoeven and van der Kraaij 1995)

${ }^{6}$ Building on Jessop's (2007) strategic relational approach, I use Cox and Negi (2010) and Mercer et al. (2003) to conceptualize the central state as socially embedded and the product of the unique historical, political, economic, and social processes operating in particular contexts.

7 The work produced by scholars associated with the African Food Security Urban Network (AFSUN) is a notable exception to this trend (African Food Security Urban Network (AFSUN) 2015).

\section{References}

African Food Security Urban Network (AFSUN). (2015). The African Food Security Urban Network (AFSUN). Available at http://www.afsun.org/.

Atkinson, S. J. (1995). Approaches and actors in urban food security in developing countries. Habitat International 19(2), pp. 151-163.

Baker, L. and de Zeeuw, H. (2015). Urban food policies and programmes. In: de Zeeuw, H. and Drechsel, P. (eds) Cities and agriculture. London, UK: Routledge, pp.26-55.

Ballard, R., Habib, A., Valodia, I. and Zuern, E. (2006). Introduction: from antiapartheid to post-apartheid social movements. In: Ballard, R., Habib, A. and Valodia, I. (eds) Voices of protest: social movements in post-apartheid South Africa. Pietermaritzburg, South Africa: University of KwaZulu-Natal Press, pp.1-22.

Battersby, J. (2012). Beyond the food desert: finding ways to speak about urban food security in South Africa. Geografiska Annaler: Series B, Human Geography 94(2), pp. 141-159.

Battersby, J. (2013). Hungry cities: a critical review of urban food security research in Sub-Saharan African cities. Geography Compass 7(7), pp. 452-463.

Beall, J., Crankshaw, O. and Parnell, S. (2002). Uniting a divided city. London, UK: Earthscan.

Bebbington, A. J., Hickey, S. and Mitlin, D. C. (2008). Introduction: can NGOs make a difference? the challenge of development alternatives. In: Bebbington, A. J., Hickey, S. and Mitlin, D. C. (eds) Can NGOs make a difference. New York, NY: Zed Books, pp.3-37.

Bohle, H. G., Downing, T. E. and Watts, M. J. (1994). Climate-change and social vulnerability-toward a sociology and geography of food insecurity. Global Environmental Change—Human and Policy Dimensions 4(1), pp. 37-48.

Bond, P. (2000). Elite transition. Sterling, VA: Pluto Press.

Bond, P. (2006). Johannesburg's resurgent social movements. In: Gibson, N. C. (ed) Challenging hegemony. Trenton, NJ: Africa World Press, pp.103-128.

Bond, P. (2008). Social movements and corporate social responsibility in South Africa. Development and Change 39(6), pp. 1037-1052.

Born, B. and Purcell, M. (2006). Avoiding the local trap: scale and food systems in planning research. Journal of Planning Education and Research 26(2), pp. 195-207.

Brenner, N. and Theodore, N. (2002). Cities and the geographies of 'actually existing neoliberalism.'. Antipode 34(3), pp. 349-379.

Bunnell, T. (2015). Antecedent cities and inter-referencing effects: learning from and extending critiques of neoliberalism. Urban Studies 52(11), pp. 1983-2000.

Cohen, M. J. and Garrett, J. L. (2010). The food price crisis and urban food (in)security. Environment and Urbanization 22(2), pp. 467-482.

Cohen, M. J. and Smale, M. (2011). Global food-price shocks and poor people- an overview. Development in Practice 21(45), pp. 460-471.

Clapp, J. and Cohen, M. J. (2009). The food crisis and global governance. In: Clapp, J. and Cohen, M. J. (eds) The global food crisis: governance challenges and opportunities. Waterloo, ON: Wilfrid Laurier University Press, pp.1-10.

Clapp, J. and Fuchs, D. (2009). Agrifood corporations, global governance, and sustainability: a framework for analysis. In: Clapp, J. and Fuchs, D. (eds) Corporate power in global agrifood governance. Cambridge, MA: Massachusetts Institute of Technology Press. 
Comaroff, J. L. and Comaroff, J. (1999). Introduction. In: Comaroff, J. L. and Comaroff, J. (eds) Civil society and the political imagination in Africa. Chicago, IL: University of Chicago Press, pp.1-43.

Comaroff, J. L. and Comaroff, J. (2012). Chapter 1: theory from the south. In: Comaroff, J. and Comaroff, J. L. (eds) Theory from the south. Boulder, CO: Paradigm Publishers, pp.1-49.

Cox, K. R. and Negi, R. (2010). The state and the question of development in Sub-Saharan Africa. Review of African Political Economy 37(123), pp. 71-85.

Crush, J. and Frayne, B. (2010). Pathways to insecurity: food supply and access in Southern African cities, Urban Food Security Series No. 3. Cape Town, South Africa: Unity Press.

Crush, J. and Frayne, B. (2011). Supermarket expansion and the informal food economy in Southern African cities: implications for urban food security. Journal of Southern African Studies 37(4), pp. 781-807.

Crush, J., Hovorka, A. and Tevera, D. (2011). Food security in Southern African cities: the place of urban agriculture. Progress in Development Studies 11(4), pp. 285-305.

De Bon, H., Parrot, L. and Moustier, P. (2010). Sustainable urban agriculture in developing countries: a review. Agronomy for Sustainable Development 30(1), pp. 21-32.

Devereux, S. (2001). Transfers and safety nets. In: Devereux, S. and Maxwell, S. (eds) Food security in Sub-Saharan Africa. Warwickshire, UK: ITDG Publishing, pp.267-293.

DeVerteuil, G. (2015). Conceptualizing violence for health and medical geography. Social Science and Medicine 133, pp. 216-222.

Dixon, C., Simon, D. and Närman, A. (1995). Introduction: the nature of structural adjustment. In: Simon, D., Spengen, W., Dixon, C. and Nbrman, A. (eds) Structurally adjusted Africa: poverty, debt and basic needs. Boulder, CO: Pluto Press, pp.1-14.

Drakakis-Smith, D. (1990). Food for thought or thought about food: urban food distribution systems in the third world. In: Potter, R. B. and Salau, A. T. (eds) Cities and development. London, UK: Mansell, pp.100-120.

Drakakis-Smith, D. (1991). Urban food distribution in Asia and Africa. The Geographical Journal 157(1), pp. 51-61.

Duncan, A. (1998). The food security challenge for southern Africa. Food Policy 23(6), pp. 459-475.

Eakin, H., Bohle, H., Izac, A., Reenberg, A., Gregory, P. and Pereira, L. (2010). Food, violence and human rights. In: Ingram, J., Ericksen, P. and Liverman, D. (eds) Food security and global environmental change. New York, NY: Earthscan, pp. $245-271$.

Eastwood, R. and Lipton, M. (2002). Pro-poor growth and pro-growth poverty reduction: meaning, evidence, and policy implications. Asian Development Review 18(2), pp. 22-58.

Edensor, T. and Jayne, M. (2012). Introduction: urban theory beyond the West. In: Edensor, T. and Jayne, M. (eds) Urban theory beyond the West. New York, NY: Routledge, pp.1-27.

Edwards, M. and Hulme, D. (1996). Introduction. In: Edwards, M. and Hulmne, D. (eds) Non-governmental organizations - performance and accountability: beyond the magic bullet. London, UK: Earthscan, pp.1-20.

Feagan, R. (2007). The place of food: mapping out the 'local' in local food systems. Progress in Human Geography 31(1), pp. 23-42.

Ferguson, J. (2006). Global shadows: Africa in the neoliberal world order. Duke: Durham, NC: University Press.

Ferguson, J. (2007). Formalities of poverty: thinking about social assistance in neoliberal South Africa. African Studies Review $50(2)$, pp. 71-85.

Food and Agriculture Organization. (2008). An introduction to the basic concepts of food security. Retrieved from http:// www.fao.org/docrep/013/a1936e/a1936e00.pdf

Food and Agriculture Organization (2009). The state of food and agriculture. Rome: Food and Agriculture Organization of the United Nations.

Fukuda-Parr, S., Yamin, A. E. and Greenstein, J. (2014). The power of numbers: a critical review of Millennium Development Goal targets for human development and human rights. Journal of Human Development and Capabilities 15(2-3), pp. 105-117.

Frayne, B. (2010). Pathways of food: mobility and food transfers in Southern African cities. International Development Planning Review 32(3-4), pp. 291-310.

Freidberg, S. (2001). Gardening on the edge: the social conditions of unsustainability on an African urban periphery. Annals of the Association of American Geographers 91(2), pp. 349-369.

Garrett, J. L. and Ruel, M. T. (1999). Are determinants of rural and urban food security and nutritional status different? Some insights from Mozambique. World Development 27(11), pp. 1955-1975.

Glassman, J. and Samatar, A. I. (1997). Development geography and the third-world state. Progress in Human Geography 21(2), pp. 164-198.

Gottlieb, R. and Joshi, J. (2010). Food justice. Cambridge, MA: Massachusetts Institute of Technology.

Greenberg, S. (2006). Urban food politics, welfare and resistance: a case study of the Southern Johannesburg Metro. Durban: Centre for Civil Society.

Habib, A. (2005). State-society relations in post-apartheid South Africa. Social Research 72(3), pp. 671-693. 
Habib, A. and Kotzé, H. (2003). Civil society, governance and development in an era of globalisation: the South African case. In: Mhone, G. and Edigheji, O. (eds) Governance in the new South Africa: the challenges of globalization. Cape Town: University of Cape Town Press, pp.246-270.

Habib, A., Maharaj, B. and Nyar, A. (2008). Giving, development and poverty alleviation. In: Habib, A. and Maharaj, B. (eds) Giving and solidarity. Cape Town: Human Sciences Research Council, pp.17-44.

Heller, P. and Evans, P. (2010). Taking Tilly south: durable inequalities, democratic contestation, and citizenship in the southern metropolis. Theory and Society 39(3-4), pp. 433-450.

Hickel, J. (2016). The true extent of global poverty and hunger: questioning the good news narrative of the Millennium Development Goals. Third World Quarterly . DOI:10.1080/01436597.2015.1109439.

Heynen, N., Kurtz, H. E. and Trauger, A. (2012). Food justice, hunger and the city. Geography Compass 6(5), pp. 304-311.

Hovorka, A. J. (2005). The (re)production of gendered positionality in Botswana's commercial urban agriculture sector. Annals of the Association of American Geographers 95(2), pp. 294-313.

Jacobs, J. M. (2012). Urban geographies I: still thinking cities relationally. Progress in Human Geography 36(3), pp. 412-422. Jessop, R. (2007). State power. Malden: Polity Press.

Koc, M., MacRae, R., Mougeot, L. J. A. and Welsh, J. (1999). Introduction: food security is a global concern. In: Koc, M., MacRae, R., Mougeot, L. J. A. and Welsh, J. (eds) For hunger-proof cities. Ottawa, ON: International Development Research Centre, pp.1-7.

Leitner, H., Sheppard, E. S., Kristin, S. and Maringanti, A. (2007). Contesting urban futures: decentering neoliberalism. In: Leitner, H., Peck, J. and Sheppard, E. S. (eds) Contesting neoliberalism: urban frontiers. New York, NY: The Guilford Press, pp.1-25.

Louw, A., Vermeulen, H., Kirsten, J. and Madevu, H. (2007). Securing small farmer participation in supermarket supply chains in South Africa. Development Southern Africa 24(4), pp. 539-551.

Maharaj, B., Habib, A., Chetty, I., Favis, M., Khan, S., Sithole, P. and Sookrajh, R. (2008). Religion and development. In: Habib, A. and Maharaj, B. (eds) Giving and solidarity. Cape Town: Human Sciences Research Council, pp.79-119.

Maxwell, D. (1999). The political economy of urban food security in Sub-Saharan Africa. World Development 27(11), pp. 1939-1953.

Maxwell, S. (2001). The evolution of thinking about food security. In: Devereux, S. and Maxwell, S. (eds) Food security in Sub-Saharan Africa. Warwickshire, UK: ITDG Publishing, pp.13-31.

McFarlane, C. (2008). Urban shadows: materiality, the 'Southern city' and urban theory. Geography Compass 2(2), pp. 340-358.

McFarlane, C. (2011). The city as assemblage: dwelling and urban space. Environment and Planning D 29(4), pp. 649-671.

McFarlane, C. and Robinson, J. (2012). Introduction-experiments in comparative urbanism. Urban Geography 33(6), pp. 765-773.

McMichael, P. and Schneider, M. (2011). Food security politics and the millennium development goals. Third World Quarterly 32(1), pp. 119-139.

Mercer, C., Mohan, G. and Power, M. (2003). Towards a critical political geography of African development. Geoforum 34(4), pp. 419-436.

Mohan, G. (2002). The disappointments of civil society: the politics of NGO intervention in northern Ghana. Political Geography 21(1), pp. 125-154.

Mohan, G. and Stokke, K. (2000). Participatory development and empowerment: the dangers of localism. Third World Quarterly 21(2), pp. 247-268.

Moragues-Faus, A. and Morgan, K. (2015). Reframing the foodscape: the emergent world of urban food policy. Environment and Planning $A$ 47(7), pp. 1558-1573.

Morgan, K. (2009). Feeding the city: the challenge of urban food planning. International Planning Studies 14(4), pp. 341-348.

Moseley, W. G. (2001). Monitoring urban food security in Sub-Saharan Africa. African Geographical Review 21(1), pp. 81-90.

Myers, G. (2011). African cities. New York, NY: Zed Books.

Myers, G. A. and Murray, M. J. (2006). Introduction: situating contemporary cities in Africa. In: Murray, M. J. and Myers, G. A. (eds) Cities in contemporary Africa. New York, NY: Macmillan. Palgrave MacMillan, pp.1-29.

Parnell, S. and Robinson, J. (2006). Development and urban policy: Johannesburg's city development strategy. Urban Studies 43(2), pp. 337-355.

Parnell, S. and Robinson, J. (2012). (Re)theorizing cities from the global south: looking beyond neoliberalism. Urban Geography 33(4), pp. 593-617.

Parnell, S., Simon, D. and Vogel, C. (2007). Global environmental change: conceptualising the growing challenges for cities in poor countries. Area 39(3), pp. 357-369.

Pearce, J. (2009). Social economy: engaging as a third system? In: Amin, A. (ed) The social economy: international perspectives on economic solidarity. London, UK: Zed Books, pp.22-33.

Peck, J. and Theodore, N. (2010). Mobilizing policy: models, methods, and mutations. Geoforum 41(2), pp. $169-174$. 
Pieterse, E. and Parnell, S. (2014). Africa's urban revolution in context. In: Parnell, S. and Pieterse, E. (eds) Africa's urban revolution. New York, NY: Zed Books, pp.1-17.

Pieterse, E., Parnell, S., Swilling, M. and van Donk, M. (2008). Consolidating developmental local government. In: van Donk, M., Swilling, M., Pieterse, E. and Parnell, S. (eds) Consolidating developmental local government. Cape Town: University of Cape Town Press, pp.1-23.

Rakodi, C. (1997). Introduction. In: Rakodi, C. (ed) The urban challenge in Africa. New York, NY: United Nations, pp.1-16.

Riches, G. and Silvasti, T. (2014). Hunger in the rich world: food aid and right to food perspectives. In: Riches, G. and Silvasti, T. (eds) First world hunger revisited. 2nd ed. New York, NY: Palgrave Macmillan, pp.1-14.

Riddell, J. B. (1992). Things fall apart again: structural adjustment programmes in sub-Saharan Africa. The Journal of Modern African Studies 30(1), pp. 53-68.

Robinson, J. (2006). Ordinary cities: between modernity and development. New York: Routledge.

Robinson, J. (2011). Cities in a world of cities: the comparative gesture. International Journal of Urban and Regional Research 35(1), pp. 1-23.

Rocha, C. and Lessa, I. (2009). Urban governance for food security: the alternative food system in Belo Horizonte, Brazil. International Planning Studies 14(4), pp. 389-400.

Roy, A. (2005). Urban informality: toward an epistemology of planning. Journal of the American Planning Association 71(2), pp. 147-158.

Roy, A. (2010). Poverty capital. New York, NY: Routledge.

Roy, A. (2011). Slumdog cities: rethinking subaltern urbanism. International Journal of Urban and Regional Research 35(2), pp. 223-238.

Sahn, D. E., Dorosh, P. A. and Younger, S. D. (1999). Structural adjustment reconsidered: economic policy and poverty in Africa. Cambridge: Cambridge University Press.

Salamon, L. M. and Anheier, H. K. (1992). In search of the non-profit sector. I: the question of definitions. Voluntas: International Journal of Voluntary and Nonprofit Organizations 3(2), pp. 125-151.

Salamon, L. M., Sokolowski, S. W. and List, R. (2003). Global civil society: an overview. Baltimore, MD: Johns Hopkins Center for Civil Society Studies.

Satterthwaite, D. (2016). Missing the millennium development goal targets for water and sanitation in urban areas. Environment and Urbanization. DOI:10.1177/0956247816628435.

Satterthwaite, D. and Mitlin, D. (2014). Reducing urban poverty in the Global South. New York, NY: Routledge.

Sayer, A. (1992). Problems of explanation and the aims of social science. In: Sayer, A. (ed) Method in social science. New York, NY: Routledge, pp.232-257.

Seleoane, M. (2008). Resource flows in poor communities: a reflection on four case studies. In: Habib, A. and Maharaj, B. (eds) . Cape Town: Human Sciences Research, pp.121-158.

Sen, A. (1981). Poverty and famines: an essay on entitlement and deprivation. Oxford, UK: Clarendon Press.

Silva, E. (2009). Challenging neoliberalism in Latin America. Cambridge, UK: Cambridge University Press.

Silvey, R. and Rankin, K. (2010). Development geography: critical development studies and political geographic imaginaries. Progress in Human Geography 35(5), pp. 696-704.

Simone, A. (2004). For the city yet to come. Durham, NC: Duke University Press.

Simone, A. (2014). Jakarta: drawing the city near. Minneapolis, MN: University of Minnesota Press.

Sonnino, R. (2014). The new geography of food security: exploring the potential of urban food strategies. The Geographical Journal . DOI:10.1111/geoj.12129.

Srinivas, N. (2009). Against NGOs? A critical perspective on nongovernmental action. Nonprofit and Voluntary Sector Quarterly 38(4), pp. 614-626.

Stevens, C. and Kennan, J. (2001). Food aid and trade. In: Devereux, S. and Maxwell, S. (eds) Food security in Sub-Saharan Africa. Warwickshire, UK: ITDG Publishing, pp.167-200.

Sullivan, K. (2008). Food crisis is depicted as 'silent tsunami'. Washington Post. 23 April 2008. Available at http://www. washingtonpost.com/wpdyn/content/article/2008/04/22/AR2008042201481_pf.html.

Thompson, L. and Tapscott, C. (2010). Introduction: mobilization and social movements in the South-the challenge of inclusive governance. In: Thompson, L. and Tapscott, C. (eds) Citizenship and social movements. New York, NY: Zed Books, pp.1-32.

Tinker, I. (1997). Street foods. Oxford, UK: Oxford University Press.

Tostensen, A., Tvedten, I. and Mariken, V. (2001). The urban crisis, governance and associational life. In: Tostensen, A., Tvedten, I. and Vaa, M. (eds) Associational life in African cities: popular responses to the urban crisis. Uppsala, Sweden: Nordiska Afrikainstitutet, pp.7-26.

United Nations (2016a). Millennium development goals. New York, NY. Retrieved from: http://www.un.org/ millenniumgoals/.

United Nations (2016b). Sustainable development goals. New York, NY. Retrieved from http://www.un.org/ sustainabledevelopment/sustainable-development-goals/. 
United Nations (2014). World urbanization prospects. New York, NY. Retrieved from http://esa.un.org/unpd/wup/Highlights/WUP2014-Highlights.pdf.

van der Hoeven, R. and van der Kraaij, F. (1995). Introduction and overview. In: van der Hoeven, R. and van der Kraaij, F. (eds) Structural adjustment and beyond in Sub-Saharan Africa. Portsmouth, NH: Heinemann, pp.1-8.

Warshawsky, D. N. (2013). Measuring the size, scope, and location of civil society organizations in Johannesburg's food system. The Professional Geographer 65(4), pp. 594-611.

Warshawsky, D. N. (2014a). Civil society and urban food insecurity: analyzing the roles of local food organizations in Johannesburg. Urban Geography 35(1), pp. 109-132.

Warshawsky, D. N. (2014b). The potential for mixed methods: results from the field in urban South Africa. The Professional Geographer 66(1), pp. 160-168.

Webb, N. L. (2011). When is enough, enough? Advocacy, evidence, and criticism in the field of urban agriculture in South Africa. Development Southern Africa 28(2), pp. 195-208.

Wiskerke, J. S. C. (2015). Urban food systems. In: de Zeeuw, H. and Drechsel, P. (eds) Cities and agriculture. London, UK: Routledge, pp.1-25.

Zezza, A. and Tasciotti, L. (2010). Urban agriculture, poverty, and food security: empirical evidence from a sample of developing countries. Food Policy 35(4), pp. 265-273. 